\title{
MEREFLEKSIKAN SAINS UNTUK ECOTEOLOGI Telaah Pemikiran Pierre Teilhard de Chardin dan Robert Spitzer
}

\author{
Christoforus Bayu Risanto
}

\begin{abstract}
:
This writing is an attempt to discuss an ecotheology from the scientific point of view. The main sentence is that reflecting on the development of science which has ecological impacts could bring human beings to the awareness of their own lives, their relation with nature, and God's presence in nature. The thoughts of two great minds, namely of Teilhard de Chardin and Robert Spitzer are being considered here and help reflect on the progress of science, mainly physics, chemistry, and biology in order to build this scientific-based ecotheology. This reflection holds its importance in today's world as we face ecological catastrophes. The culprit is human's voracity of energy to develop their lives, mainly in economic basis. Science that primarily serves human knowledge to search and find out the unknown regions of the universe is also able to serve the development of technology especially which generates energy. Since then, human beings exploit the sources of energy such as crude oil, coal, natural gas, and uranium, and in doing so they destroy Mother Nature and foul her with poisonous wastes.
\end{abstract}

\section{Kata-kata Kunci:}

Sains, teknologi, energi, ecoteologi, kerusakan lingkungan.

\section{PENDAHULUAN}

\subsection{Latar Belakang}

Pada tanggal 11 Maret 2011, Negeri Sakura, Jepang, dilanda tiga bencana sekaligus, yaitu gempa bumi, tsunami, dan terbakarnya intalasi Pembangkit Listrik Tenaga Nuklir (PLTN). Korban tewas dan hilang akibat terjangan gelombang laut setinggi 10 meter merangkak naik hingga 20.000 orang dalam lima hari pasca bencana. Tetapi korban yang mencakup berbagai hal selain manusia terus meluas dan berkepanjangan karena kebakaran PLTN itu melepaskan radiasi atomik. Hari ke-26 setelah bencana gempa bumi itu, surat-surat kabar memberitahukan bahwa zat radioaktif dan radiasinya sudah mengkontaminasi air-air ledeng di Tokyo, produk susu, dan sayuran di sejumlah prefektur.
Bencana ini terjadi karena keinginan manusia untuk memenuhi kebutuhan energi yang murah demi kemajuan dalam bidang ekonomi. Polusi udara, terutama penumpukan karbon dioksida (CO2) dan rusaknya ecosistem sungai karena bendungan juga terjadi karena keinginan manusia akan energi murah dan melimpah. Ternyata sains yang berkembang sejak abad XVI hingga abad XXI memberi andil besar dalam penciptaan mesin-mesin penghasil energi. Kita prihatin karena sains semata-mata digunakan untuk menghasilkan teknologi yang merusak lingkungan.

\subsection{Rumusan Masalah}

Bukankah sains dapat mengantar manusia pada kesadaran siapa dirinya dan kehadiran sang pencipta sendiri di alam semesta? Bukankah sains pada awalnya merupakan usaha manusia untuk mengetahui rahasia alam semesta? 


\subsection{Tujuan Penulisan}

Tujuan dari tulisan ini adalah untuk menjelaskan bahwa sains yang menggerakkan teknologi memungkinkan manusia untuk menyadari siapa dirinya, hubungannya dengan alam semesta, dan kehadiran Tuhan di alam semesta. Semuanya itu membawa kepada sikap ecosentrisme dan pada akhirnya memberi dasar yang kokoh bagi ecologi dan ecoteologi. Dalam ecosentrisme, segala sesuatu menjadi pusat dan menjadi penting karena alam semesta ini dipandang sebagai suatu jaringan di mana materi yang satu terhubung dengan materi yang lain untuk melestarikan keberadaannya. Jadi, ada kesalingterhubungan (interconnectedness) di antara seluruh materi. Lebih dari itu, setiap materi entah mati atau hidup memiliki nilai intrinsik pada dirinya sendiri

\subsection{Metode Penulisan}

Tulisan ini menggunakan metode reflektif dengan mengacu pada pemikiran Pierre Teilhard de Chardin dan Robert Spitzer. Teilhard, seorang imam Jesuit dan paleontolog, mengatakan dalam bukunya Le Phenoménè Humain (The Phenomenon of Man) bahwa sejarah alam semesta adalah suatu evolusi kesadaran karena ia meyakini bahwa setiap materi memiliki kesadaran dalam taraf yang berbeda-beda. Dari keterkaitan satu materi dengan materi lain, ia melihat adanya suatu proses perkembangan kesadaran (consciousness) yang meningkat terus menerus dari materi yang mati hingga menjadi materi yang mampu berefleksi. Sejarah alam semesta, secara ringkas, digambarkannya sebagai tahapan-tahapan kesadaran. Robert Spitzer adalah seorang imam Jesuit yang menggeluti filsafat sains. Buku terbarunya New Proofs for the Existence of God sedikit pun tidak mengupas masalah ecologi, tetapi pendasaran argumennya adalah bahwa alam semesta termasuk manusia berasal dari bahan baku yang sama, dari materi yang sama. Selain itu dalam setiap materi terdapat realitas yang tak bersyarat, yaitu Tuhan sendiri.

Keduanya memberikan cara baru melihat materi di alam semesta. Di dalam setiap materi terdapat ciri ontologis yang memberi alasan kuat bagi kita untuk hormat pada alam semesta ini, khususnya Ibu Bumi. Alhasil, tulisan ini membawa cara berteologi secara baru, yaitu melibatkan sains, khususnya ilmu pengetahuan alam, dalam refleksinya. Di sini diandaikan orang memahami dasar-dasar sains supaya refleksi teologis memiliki bobot ilmiah, bukan hanya biblis-historis.

\section{PANORAMA ECOLOGI DAN TEKNOLOGI}

Isu mengenai kerusakan lingkungan hidup mulai bertiup kencang sekali pada pertengahan abad XX terutama sejak laporan kerusakan lingkungan dari Klub Roma pada tahun 1972, dan semakin banyak orang menaruh perhatian ke sana pada awal abad XXI. Salah satu penyebab yang paling bertanggung jawab adalah pengembangan dan penggunaan sains untuk teknologi penghasil energi. Sebut saja tiga yang besar, yaitu reaktor nuklir, mesin-mesin berbahan bakar fosil dan bendungan untuk Pembangkit Listrik Tenaga Air (PLTA).

\subsection{Panorama Ekologi}

Peristiwa besar yang menandai runtuhnya kepercayaan masyarakat dunia pada teknologi nuklir adalah bencana kebakaran reaktor nuklir Fukushima, Jepang, pada bulan Maret 2011. Meski kecelakan serupa pernah terjadi di Chernobyl dan Three Mile Island, peristiwa Fukushima sangat menggemparkan karena terjadi di negara yang berteknologi tinggi dan punya sistem pengaman mutakhir. Alam ternyata jauh lebih kuat dari teknologi manusia. Kebakaran adalah akibat gempa bumi dan terjangan tsunami.

Banyak ahli menduga bahwa batang-batang bahan bakar yang berupa Uranium $\left(\mathrm{U}^{235}\right)$ dan Plutonium $\left(\mathrm{Pu}^{238}\right)$ itu sudah meleleh karena panas yang tidak terkendali dan tidak tersalurkan. Kebakaran itu menebarkan partikel radioaktif yaitu isotop ${ }^{1}$ Yodium $\left(\mathrm{I}^{131}\right)$ dan isotop Cesium $\left(\mathrm{Cs}^{137}\right)$ ke udara. Keduanya yang merupakan hasil sampingan dari reaksi fisi ${ }^{2}$ nuklir bukan hanya beracun tapi juga memancarkan radiasi $\gamma$ (gamma) yang dapat mengganggu metabolisme tubuh makhluk hidup dan dapat menyebabkan kanker. ${ }^{3}$ Makhluk hidup dapat terkontaminasi partikel radioaktif ini lewat makanan dan air yang dikonsumsi, serta udara yang dihirup. Otoritas Jepang mendeteksi tingkat radiasi nuklir sudah di luar batas toleransi pada produk susu, sayuran, dan air ledeng. Sebaran radiasi bahkan terdeteksi di luar radius $80 \mathrm{~km}$ dari PLTN yang 
meledak itu. ${ }^{4}$ Pada awal April, pemerintah melarang warganya mengkonsumsi hewan laut yang ditangkap di seluruh perairan Jepang karena tercemar radioaktif.

Sebelum era nuklir dimulai, orang menggantungkan sebagian besar sumber energi pada pembakaran bahan bakar fosil, yaitu minyak, gas, dan batubara. Hingga tahun 2010, diperkirakan pembakaran bahan bakar ini mengemisikan 90 juta ton $\mathrm{CO}_{2}$ ke atmosfer setiap harinya. Kendaraan bermotor (transportasi), industri, dan Pembangkit Listrik Tenaga Uap (PLTU) adalah penyumbang $\mathrm{CO}_{2}$ terbesar ke atmosfer. Lebih dari $40 \%$ listrik dunia masih dihasilkan dari batubara, sementara $20 \%$ dari gas alam.

Kini semakin diyakini oleh banyak orang bahwa $\mathrm{CO}_{2}$ yang diemisikan ke udara dalam jumlah besar itu menjadi salah satu sebab terjadi perubahan iklim global. $\mathrm{CO}_{2}$ yang dikenal umum sebagai salah satu gas rumah kaca memang memiliki sifat seperti rumah kaca, tempat menanam tanaman pangan di daerah beriklim subtropis, yaitu memerangkap panas matahari. $\mathrm{CO}_{2}$ memerangkap infra merah atau panas matahari yang dipantulkan bumi ke luar angkasa. Panas yang seharusnya bisa terlepas itu terserap oleh $\mathrm{CO}_{2}$ yang berakumulasi di atmosfer. Selain gas $\mathrm{CO}_{2}$, ada sejumlah partikel lain hasil dari pembakaran bahan bakar fosil yang menyumbang perubahan iklim. Di antaranya adalah karbon hitam, metana, dan halokarbon.

Akibat dari perubahan iklim adalah suhu air laut meningkat; suhu udara di berbagai tempat meningkat sementara di beberapa tempat lain turun drastis; es di kedua kutub bumi mencair hingga diramalkan meningkatkan ketinggian permukaan air laut dalam beberapa tahun ke depan; cuaca menjadi semakin tidak teratur.

Dibandingkan dua pengada energi di atas, PLTA jauh lebih ramah lingkungan karena hampir tidak menghasilkan $\mathrm{CO}_{2}$ maupun bahan berbahaya lainnya. Namun pembangunan bendungan-bendungan secara ekstensif demi pengadaan energi listrik menjadikannya ancaman bagi lingkungan juga. Mulai tahun 2000-an, negara-negara Indocina, khususnya Kamboja dan Vietnam mulai angkat bicara soal kerusakan lingkungan hidup karena Sungai Mekong, terpanjang kelima di dunia, mulai dibendung oleh negara-negara hulu, terutama China. Pembangunan itu terutama untuk PLTA dan irigasi pertanian. Akibatnya, debit air turun, migrasi ikan terganggu, populasi ikan menurun, dan gerak sedimen terhambat.

Dengan demikian dapat dengan mudah diramalkan apa yang akan terjadi jika pembangunan bendungan-bendungan secara ekstensif itu terus terjadi dalam 10 hingga 20 tahun mendatang. Dalam ranah ecologi, kiranya akan terjadi sekurang-kurangnya tiga hal. Pertama, bendungan-bendungan itu akan mengubah hidrologi sungai dan kualitas airnya. Kedua, habitat ikan akan mengalami perubahan. Pada beberapa bagian sungai, ikan akan sulit ditemukan lagi. Ketiga, bendungan-bendungan itu akan mengubah keanekaragaman hayati. Sejumlah spesies endemik mungkin akan punah.

Ketersediaan energi dari berbagai sumber itu menuntut ketersediaan bahan-bahan lain agar kemajuan ekonomi dan peradaban semakin terlihat nyata. Bahan-bahan itu terutama dibutuhkan oleh industri-industri berat untuk membangun mesin-mesin dan peralatan yang dibutuhkan manusia sehari-hari. Di antara bahan-bahan yang dibutuhkan itu adalah bijih besi, tembaga, mangan, nikel, dan timah yang didapat dengan cara menambang. Penambangan bahan-bahan inilah yang kerapkali menimbulkan masalah lingkungan karena proses pengambilan bahan tambang tidak memperhitungkan kelestarian lingkungan hidup. Sayangnya hal ini sering terjadi di negara-negara miskin dan berkembang.

Pengada energi dan industri juga membutuhkan bahan-bahan lain dari alam seperti kelapa sawit. Selain digunakan dalam industri makanan, minyak kelapa sawit juga dicampur dengan bahan bakar diesel untuk membuat salah satu bentuk utama biodiesel. Pembukaan berhektar-hektar lahan kelapa sawit dengan cara penebangan dan pembakaran pohon-pohon serta pembukaan lahan gambut menyumbang lebih banyak CO2 ke atmosfer. Sampai sini kita sudah melihat bahwa penggunaan sains untuk teknologi yang menghasilkan energilah yang bertanggung jawab atas kerusakan lingkungan hidup.

\subsection{Panorama Teknologi}

Dalam sejarah peradaban manusia, keterhubungan antara teknologi dan sains tidak langsung terbentuk secara serta merta. Keduanya baru terhubung kurang lebih pada abad XVI dan XVII. Titik yang diacu dalam sejarah biasanya 
adalah pemikiran filsafat Francis Bacon (15611662) yang secara ringkas mengatakan bahwa dengan ilmu pengetahuan, manusia dapat sungguh menjadi tuan atas segala ciptaan di dunia ini. Ia mendirikan suatu kelompok yang terdiri dari para filsuf, pengerajin, dan pekerja manual. Tujuannya adalah agar para filsuf yang secara intelektual dan filosofis menguasai ilmu pengetahuan, belajar dari para pengerajin dan pekerja manual yang menguasai teknik konstruksi, pengolahan logam dan semacamnya. Kelompok ini kemudian menjadi Royal Society, organisasi ilmuwan di Inggris yang berdiri tahun 1660.

Keterpautan antara sains dan teknologi ini terlihat nyata dalam terciptanya mesin uap oleh James Watt di Inggris tahun 1781. Dalam waktu sekejap, permintaan batubara meningkat sebagai bahan bakar mesin uap. Secara berangsur-angsur berbagai cabang sains ikut ambil bagian baik melalui pemikiran maupun upaya teknis untuk membangun mesin uap yang lebih baik. Dapat disebutkan di antaranya adalah teori matematika tentang roda gigi yang ditulis oleh Leonhard Euler (1707-1783) tahun 1760; teori panas dan termodinamika yang dipelajari James Watt dalam kuliah-kuliah Joseph Black; metode pengukuran elastisitas dan tegangan logam serta gaya gesek pada mesin yang disusun oleh Charles-Augustin de Coulomb (1736-1806); teknik pembuatan besi dan baja oleh Réne-Antoine Reamur (1683-1757) dan Pieter van Musschenbroek (1692-1761); serta teori mengenai keterkaitan antara tekanan, volume, dan suhu gas oleh Amadeo Avogadro (1776-1856), yang dicetuskan pada tahun 1811 dan dikenal sebagai hukum Avogadro pada tahun 1858.

Dalam waktu bersamaan, dikembangkan pula mesin-mesin yang berbahan bakar gas dan bensin. Yang mengembangkan di antaranya adalah Gottlieb Daimler (1834-1900) dan Carl Benz (1844-1929) secara terpisah. Merekalah yang menciptakan mesin mobil pertama di dunia. Alhasil permintaan akan bensin dan gas meningkat sebanding dengan peningkatan jumlah mobil. Selain itu, dikembangkan juga mesin berbahan bakar minyak diesel oleh Rudolf Diesel (1858-1913). Diesel yang semula adalah limbah penyulingan minyak diketahui menghasilkan panas empat hingga lima kali lebih efisien dibandingkan batubara yang menggerakkan mesin uap.
Sumber energi baru yang disebut energi nuklir ditemukan karena perkembangan fisika partikel (atom). Para fisikawan, khususnya Ernst Rutherford (1871-1937) menemukan nukleus atau inti atom yang menurut observasi dan perhitungan matematis memiliki energi yang besar karena mengikat proton dan neutron.

Barulah pada tahun 1938, ditemukan suatu cara untuk mendapatkan energi dari nukleus atom. Dua orang yang berjasa adalah Otto Frisch (1904-1979) dan Lise Meitner (1878-1968). Keduanya menemukan bahwa uranium yang dibombardir dengan neutron berubah menjadi unsur yang disebut barium, yang massanya persis setengah dari massa uranium, melepaskan tiga neutron, dan energi panas. Inilah yang kemudian menjadi inti dari pengada energi berbasis reaksi nuklir, yang secara nyata diterapkan dalam instalasi-instalasi pembangkit listrik tenaga nuklir.

\section{DARI MATERI SAMPAI ECOTEOLOGI À LA TEILHARD DAN SPITZER}

\subsection{Pemikiran Teilhard}

Pierre Teilhard de Chardin dan Robert Spitzer tidak mengambil jalan yang umumnya diminati oleh para ilmuwan dan praktisi teknologi, yaitu menerapkan sains demi kepentingan teknologi. Sebaliknya, keduanya merefleksikan kemajuan sains, khususnya dalam bidang fisika, kimia, dan biologi, bahkan paleontologi hingga membuka kemungkinan bagi kita suatu pemikiran logis untuk menghargai dan merawat alam semesta dan menyadari kehadiran Tuhan.

Dalam mahakaryanya Le Phenoménè Humain, Teilhard pertama-tama menyatakan bahwa materi sebagaimana diterangkan oleh fisika, kimia, dan biologi hanyalah materi sejauh tercerap indera, yaitu hanya permukaannya saja. Ia mengistilahkan apa yang dilihat hanyalah sisi-luar dari materi (le dehors des Choses). Tetapi ia memuji pencapaian sains yang dalam bahasanya sudah berhasil melihat materi dalam kemajemukannya, kesatuannya satu sama lain, serta potensi energi yang ada di dalamnya. Sains juga berhasil memetakan evolusi materi terutama karena kemajuan fisika atom. Lepas dari semua itu, Teilhard meyakini bahwa materi memiliki sisi-dalam (le dedans des Choses) karena ia mengamati adanya sejumlah anomali pada materi. 
Pertama, ketika materi-materi itu ditempatkan pada lapisan alam yang berbeda, sifat dan perilakunya berubah. Lapisan alam yang dimaksud di sini adalah kerangka acuan dan durasi yang biasa dipakai dalam fisika dan matematika. Massa dan panjang materi berubah ketika ia bergerak mendekati kecepatan cahaya. Hal ini agak sulit dipahami dalam konteks dunia keseharian manusia karena kecepatan suatu benda tidak mengubah apa-apa pada benda itu. Unsur-unsur kimia, pada umumnya, stabil dan bertahan lama. Penemuan radium mengubah persepsi kita karena sebenarnya setiap materi di alam semesta, termasuk tubuh kita, melepaskan radiasi. Perlu kita ingat, bahwa Teilhard adalah seorang paleontolog yang sungguh paham penaksiran umur dengan karbon 14.

Kedua, sains sampai pada pemahaman bahwa kerak bumi dan bintang-bintang serta galaksi di alam semesta bergerak. Dalam durasi hidup manusia, hal ini tidak terasa sama sekali. Semua posisi dan struktur mereka seolah-olah terlihat sama saja dari waktu ke waktu, padahal mereka semua mengalami perubahan. Semua irregularitas alam semesta ini membuat kita manusia sulit mengenali dasar ontologis dari eksistensi mereka. Para ilmuwan hanya berhenti pada sisi-luar dari benda-benda saja.

Ketiga, yang mendasari pencarian sisi-dalam materi adalah kesadaran bahwa cara pandang para ahli fisika, biologi, dan kimia dari sisi-luar saja tidak cukup untuk diterapkan pada manusia. Ada sisi-dalam di dalam susunan materi yang membentuk tubuh manusia. Sisi-dalam ini disebut kesadaran. Jika radiasi pada radium masih dapat dipandang sebagai sisi-luar materi karena masih dapat dihitung dan dapat diprediksi, kesadaran tidak dapat dihitung dan diprediksi. Kesadaran disebut sebagai bukti paling nyata dari eksistensi sisi-dalam materi. Kesadaran hanya dikenali secara utuh di dalam diri manusia. Karena itu, ini merupakan hal yang dalam arti tertentu terpisah dari sains.

Adanya kesadaran dalam diri manusia sudah menunjukkan adanya perpanjangan (extension) kosmis baik secara spasial maupun temporal. Materi tidak sekadar sisi-luar saja, atau apa yang tercerap oleh pikiran dan indera-indera kita. Sebaliknya, ada suatu kedalaman di balik bahan alam semesta. ${ }^{5}$ Ia yakin bahwa dalam setiap materi ada kesadaran. Dari pengamatannya, ia menemukan hubungan antara kuantitas materi dengan kualitas kesadaran. Prinsipnya adalah semakin kompleks dan terorganisasi suatu struktur materi, semakin berkembang pula kesadaran pada materi itu. Kompleksitas materi dan kesadaran ini terjadi lewat proses granulasi, di manat materi tergabung dan terkait satu sama lain menjadi struktur yang lebih kompleks. Dengan kata lain, materi sudah memiliki kesadaran, terlebih tumbuhan dan hewan, meski kesadaran mereka tidak setaraf dengan kesadaran manusia.

Teilhard sendiri tidak tahu dan tidak pernah menganggap dirinya tahu bagaimana kehidupan di Bumi ini muncul atau bagaimana kesadaran dalam materi itu melompat dan terlihat nyata di dalam materi yang hidup. Yang pasti adalah bahwa berubahnya materi mati menjadi materi yang hidup bukan merupakan proses kontinu yang sederhana, tapi lebih sebagai tibanya suatu proses pada suatu titik kematangan, suatu gerbang, suatu permulaan tatanan baru. ${ }^{6}$ Ini adalah suatu pencapaian di mana evolusi mencapai titik kritis; materi yang mati menjadi hidup. Di sinilah fisika dan biologi bertemu. Menurut biologi, sel adalah butiran kehidupan; menurut fisika, sel adalah butiran materi elementer. Perubahan dari megamolekul menjadi mikro-organisme adalah suatu titik kematangan.

Para ahli ilmu alam pada masa Teilhard semakin diyakinkan bahwa lahirnya kehidupan di muka Bumi adalah suatu peristiwa unik yang hanya terjadi satu kali saja sepanjang sejarah evolusi alam semesta. Perubahan dari litosfer-hidrosfer menjadi biosfer hanya satu kali saja. Kemunculan biosfer di Bumi ini secara serta-merta mengganggu, memiskinkan, dan mengurangi unsur-unsur kimia purba pada litosfer dan hidrosfer sehingga kejadian lahirnya kehidupan tidak terulang lagi. ${ }^{7}$

Dalam konteks pemikiran Teilhard, hal yang penting adalah munculnya kesadaran yang terus meningkat hingga lahirlah pikiran. Pikiran adalah suatu kemampuan untuk melihat dirinya sendiri. Dalam bahasa filsafat, kemampuan ini disebut kemampuan berefleksi. Meski banyak ahli menyatakan evolusi sebagai gerak acak metamorfosis makhluk hidup, Teilhard sendiri menyatakan optimis bahwa evolusi ini terarah, yaitu terarah pada munculnya kesadaran yang berpuncak pada pikiran. Evolusi secara mendasar adalah perkembangan psikis. Pikiran adalah hasil pendalaman kesadaran.

Kesadaran bukanlah privilese manusia saja. Hewan pada tingkat tertentu memiliki kesadaran 
yang dapat teramati. Kesadaran itu sebanding dengan perkembangan evolutif otak mereka. Perkembangan otak ini disebut cerebralisasi, yaitu berkembangnya syaraf-syaraf primitif menjadi suatu organ yang disebut otak, yang mengatur fungsi tubuh makhluk hidup. Di antara organisme bertulang belakang, mamalia adalah makhluk yang memiliki volume otak paling besar dengan jaringan syaraf paling rumit.

Dalam keluarga mamalia, primata adalah yang mempertahankan bentuk primitif struktur tubuhnya. Tidak ada perubahan pada tungkai kaki, lengan, dan jari-jemarinya. Alih-alih mengubah struktur tersebut seperti mamalia lain, primata mengembangkan struktur otaknya dan kesadarannya menjadi semakin meningkat. Antropoid, salah satu cabang primata, melampaui batas tertinggi kesadaran, yaitu menjadi mampu melihat dirinya sendiri sebagai makhluk berkesadaran; ia mampu berpikir dan berefleksi. Dalam bahasa Perancis diistilahkan non plus seulement connaître, mais se connaître; non plus seulement savoir mais savoir que l'on sait. ${ }^{8}$ Dengan kata lain, organisme dapat menjadikan dirinya objek bagi pikirannya.

Kemampuan ini adalah milik manusia. Memang primata, mamalia, dan hewan-hewan lain dapat tahu, tetapi sayangnya mereka tidak tahu bahwa mereka tahu. Fenomena refleksi ini secara spiritual dapat dibaca sebagai suatu transendensi dari hewan yang disebut manusia; secara material, ini dapat dibaca sebagai hewan yang mengalami kemajuan pesat dalam cerebralisasinya, yang memuncak pada lompatan dari insting ke pikiran. Dengan adanya hominisasi ini, Bumi tidak hanya diselubungi lapisan biosfer, tapi juga lapisan noosfer, lapisan yang mampu berefleksi. Lapisan ini mampu memengaruhi kondisi Bumi, entah menjadi baik atau buruk.

Evolusi kesadaran ini tidak berhenti pada pikiran. Kesadaran itu terus bertambah hingga berpuncak pada titik Omega. Titik Omega adalah suatu pusat yang khas, yang memancar pada inti suatu sistem; suatu pengelompokan di mana personalisasi dari keseluruhan, dan personalisasi dari elemen-elemen mencapai puncaknya, secara bersama-sama tanpa melebur di bawah pengaruh suatu pusat kesatuan yang otonom. ${ }^{9}$ Secara singkat, titik Omega adalah suatu kesadaran agung yang membuat manusia dapat hidup berdampingan dengan sesamanya dan alam semesta.
Maka intinya adalah pertama, di dalam setiap materi di alam semesta ini, ada kesadaran; dan karenanya, setiap materi memiliki nilai pada dirinya sendiri (nilai intrinsik); kedua, evolusi alam semesta adalah evolusi yang terarah pada lahirnya kesadaran dan pikiran; ketiga, manusia adalah lapisan noosfer yang dapat memengaruhi Bumi.

\subsection{Pemikiran Spitzer}

Spitzer membuka diskusi dalam bukunya dengan bicara mengenai alam semesta yang hampir pasti memiliki awal mula. Bahwa alam semesta memiliki awal mula adalah penting sebagai titik pijak argumen bahwa ada sesuatu di luar alam semesta yang menyebabkan alam semesta ini ada. Alasan bahwa alam semesta berawal adalah pertama, penemuan oleh Edwin Hubble dan para astronom mengenai mengembangnya alam semesta. Pada masa lalu, tentu semua materi di alam semesta ini letaknya saling berdekatan pada suatu ruang terbatas.

Alasan kedua, menurut Hukum Termodinamika 2, semua sistem di alam semesta cenderung menjadi aus, habis, kacau, dan akhirnya mengalami dekomposisi. Relevansinya adalah tidak ada mesin yang bergerak secara abadi, yang tidak pernah aus dan tidak pernah mengalami dekomposisi. Jika alam semesta ini tidak memiliki awal mula, ia sudah ada dari tak-berhingga sampai tak-berhingga. Dalam konteks termodinamika, hal yang seperti ini tidak mungkin. Karena ketidakmungkinan inilah, alam semesta pada suatu ketika akan mengalami aus dan habis, atau sekurang-kurangnya tingkat entropi semakin tinggi. Dan, yang lebih penting, alam semesta tentu memiliki awal mula di suatu titik waktu di masa lalu.

Alasan ketiga, kosmologi kuantum mempersulit gambaran singularitas ruang-waktu. Dalam geometri ruang-waktu, big bang (peristiwa dentuman besar lahirnya alam semesta) sering digambarkan sebagai kerucut. Ujung runcing dari kerucut itu menggambarkan singularitas ruangwaktu di mana $\mathrm{t}=0$ detik, sementara diujung yang lain ruang-waktu di masa kemudian. Dalam kosmologi kuantum, ujung runcing kerucut itu dipertanyakan, apakah benar-benar runcing. Di bawah lensa mikroskop, ujung itu tidaklah terlihat runcing lagi, melainkan suatu permukaan datar yang luas secara relatif, tanpa singularitas seperti yang diramalkan. Karena itulah ruangwaktu tetap berhingga, dan bermula di masa lalu. 
Jika awal mula alam semesta adalah masuk akal dan hampir pasti terjadi di mana sebelumnya tidak ada realitas fisis apapun, dan jika dari ketiadaan hanya menghasilkan ketiadaan sebagaimana ditulis oleh Parmenides dalam argumen metafisikanya - dan ini secara apriori benar, maka adalah sangat masuk akal bahwa alam semesta ini berasal dari sesuatu yang bukan realitas fisis sama sekali. Ini biasanya disebut sebagai "causa transenden dari alam semesta (realitas fisis)" atau "pencipta alam semesta".

Keyakinan dan kemasukakalan "causa transenden" ini semakin kuat dengan ditemukannya konstanta-konstanta di alam semesta. Konstanta adalah suatu kuantitas universal yang bersifat tetap dan secara matematis mengatur persamaanpersamaan fundamental alam semesta. Contohnya adalah konstanta kecepatan cahaya 300.000 km/ detik dan konstanta gravitasi yang besarnya $6.67 \times 10^{-11}$. Karena mereka punya kuantitas tertentu, pasti, dan ikut dalam membentuk struktur alam semesta, maka konstanta dan interaksinya membentuk wajah alam semesta yang tertentu dan spesifik pula.

Alam semesta kita ini hanyalah satu dari miliar miliaran kemungkinan alam semesta yang dapat terjadi. Spitzer menyebut alam semesta yang kita diami ini sebagai alam semesta antropis karena melahirkan kehidupan yang mampu berpikir. Andaikata konstanta gravitasi adalah $6.00 \times 10^{-11}$, kehidupan tidak mungkin terbentuk karena bintang yang memetamorfosis hidrogen menjadi karbon - bahan dasar kehidupan - tidak lahir. Kemunculan alam semesta yang kita diami ini hanya satu per sepuluh pangkat sepuluh pangkat seratus dua puluh tiga kemungkinan $\left(1 / 10^{10^{123}}\right)$. Pertanyaannya adalah mungkinkah kita tanpa penjelasan ilmiah yang memadai percaya bahwa kemunculan alam semesta yang antropis ini hanyalah suatu kebetulan semata. Bukankah lebih masuk akal jika kita percaya bahwa ada perancang supranatural agung yang membuat alam semesta ini.

Penemuan ini mengubah kosmologi Newtonian yang tidak membutuhkan pencipta, memandang alam semesta sebagai yang tidak berhingga dalam hal umur dan kekayaan interaksi berbagai elemen di dalamnya. Dengan temuan baru di atas, jumlah kemungkinan interaksi antar materi, energi, ruang, dan waktu menurun menjadi berhingga. Kemungkinan bentuk wajah alam semesta pun berhingga. Maka dari itu, kita menjadi sadar bahwa alam semesta kita terbatas, bahkan Bumi kita pun terbatas.

Dalam buku ketiganya, Spitzer berargumen dalam ranah fisika kuantum dan metafisika. Ia menunjukkan bahwa Tuhan hadir dalam setiap materi. Kehadiran ilahi ini menjadi alasan kuat khususnya bagi orang beriman bahwa materi memiliki nilai pada dirinya sendiri, nilai interisik, suatu nilai yang tidak ditentukan olah manusia. Menurut fisika kuantum, materi tersusun atas materi yang lebih kecil dan sederhana. Karena itu, eksistensi materi bergantung pada eksistensi materi penyusunnya. Dalam bahasa Spitzer semua materi adalah realitas bersyarat karena ada mereka bergantung pada realitas lain yang menyusunnya.

Seekor kucing adalah suatu realitas bersyarat karena kucing bergantung pada sel-sel dan struktur sel untuk eksistensinya. Tanpa sel-sel, dan struktur sel-sel itu, kucing tadi tidak ada. Sel-sel itu adalah realitas bersyarat. Eksistensi mereka bergantung pada molekul dan struktur molekul. Molekul-molekul itu adalah realitas bersyarat karena bergantung pada atom serta struktur atom. Atom juga bergantung pada quark dan struktur quark. Terus menerus terjadi seperti itu.

Dengan demikian mustahil bahwa suatu realitas bersyarat terdiri dari realitas bersyarat dengan jumlah tak berhingga. Pada bagian yang paling akhir dan dasar harus ada realitas tak-bersyarat yang mendasari seluruh realitas bersyarat dan eksistensinya. Realitas takbersyarat ini penuh pada dirinya sendiri dan mengada melalui dirinya sendiri (through itself).

Realitas yang tak-bersyarat itu harus realitas yang sederhana secara mutlak karena ia mengada bukan melalui pemenuhan atas syarat-syarat yang diperlukan seperti pada realitas bersyarat, tapi melalui ketiadaan syarat untuk mengada. Kesederhanaan mutlak berarti ketiadaan batasbatas intrinsik maupun ekstrinsik, keberhinggaan, dan segala pembatasan (restriction) dalam realitas. Batasan menyebabkan eksklusi, pengecualian, dan ketiadaan interaksi dengan realitas lain di luar dirinya. Ketika suatu realitas semakin sederhana, batasan intrinsik dan ekstrinsiknya berkurang.

Realitas tak-bersyarat itu haruslah suatu ketunggalan mutlak. Apakah realitas takbersyarat yang paling sederhana ini hanya satu saja atau banyak? Kalau ada banyak, realitas- 
realitas tak-bersyarat itu bukanlah yang paling sederhana karena ada realitas lain yang membuat setiap realitas itu berbeda dari yang lain. Konsekuensinya adalah muncul proses eksklusi antar realitas. Karena itulah, realitas tak-bersyarat itu harus tunggal.

Realitas tak-bersyarat itu adalah pencipta segala sesuatu yang ada, dan yang mencipta secara terus menerus/ berkelanjutan. Kembali kepada kucing. eksistensi dan struktur dari sel-sel pada hewan kucing hanyalah syarat yang hampir mendekati kepenuhan hewan yang disebut kucing. Sementara kucing sebagai "ciptaan" mengacu pada kepenuhan total atas syarat-syarat bagi realitas bersyarat yang disebut kucing. Kepenuhan total ini disebabkan karena adanya suatu realitas tak-bersyarat. "Pencipta" adalah sumber yang memenuhi syarat-syarat secara total bagi segala realitas bersyarat. Sumber atau kekuatan ini tidak lain adalah realitas takbersyarat itu sendiri.

Penciptaan adalah pemenuhan total syaratsyarat oleh realitas tak-bersyarat. ${ }^{10}$ Pada dasarnya, definisi ini tidak bertentangan dengan creatio ex nihilo. Definisi ini justru mencakup juga kemungkinan bahwa pencipta secara terus-menerus memenuhi syarat-syarat yang diperlukan bagi realitas bersyarat, dan dengan demikian mempertahankan dan melestarikan realitas-realitas bersyarat dalam adanya.

\subsection{Refleksi Sains sampai Ecoteologi}

Pertama, pemikiran Teilhard dan Spitzer menyentuh segala materi. Keduanya berpendapat bahwa materi terutama benda mati, bukanlah sesuatu yang mati dan tanpa arti sama sekali. Di dalam materi ada kesadaran meski dalam taraf yang masih sederhana, serta hadir pula realitas tak-bersyarat (Tuhan). Tentu saja materimateri ini berguna untuk membentuk kehidupan sehingga bukan tanpa arti sama sekali.

Cara pandang Teilhard dan Spitzer mengenai materi ini mensakralkan kembali segala realitas material. Ini berarti mensakralkan kembali Bumi dan secara luas alam semesta. Apakah kesakralan itu pernah hilang? Ya pernah hilang terutama ketika ilmu pengetahuan ilmiah berkembang dan didukung oleh filsafat terutama Francis Bacon. Seperti halnya Spitzer, Teilhard juga berpandangan bahwa setiap materi mengandung keilahian karena di dalamnya terdapat kesadaran yang sejak semula mengarah pada kesadaran yang paling tinggi, yaitu titik Omega. ${ }^{11}$

Tentu saja ini bukan berarti bahwa kedua cara pandang ini masuk ke dalam sikap panteisme yang memandang seluruh isi alam semesta sebagai imanensi dari yang ilahi sehingga antara yang pencipta dan ciptaan tidak ada bedanya sama sekali. Alam semesta dipandang sakral karena di dalamnya diakui kehadiran sesuatu yang bukan material, yang memberi ada pada alam semesta itu sendiri. Ini adalah cara pandang panenteisme di mana tetap ada perbedaan antara ciptaan dan pencipta. Namun demikian pencipta tetap hadir dalam segala ciptaan.

Sekitar tahun 1970-an, isu mengenai kerusakan lingkungan hidup, khususnya masalah polusi, muncul kepermukaan sebagai isu global berkat laporan ilmiah dari Klub Roma dalam buku The Limits to Growth yang terbit tahun 1972. Itulah kiranya kali pertama, umat manusia berpaling pada yang bukan manusia, yang mencakup hewan, tumbuhan, dan lingkungan tempat di mana ia tinggal. Manusia sadar bahwa kehidupannya tidak akan berlangsung dan tidak akan lestari tanpa dukungan jaringan kehidupan dan jaringan tempat tinggal yang baik.

Dalam konteks perubahan iklim dan kerusakan lingkungan saat ini, dapat dikatakan bahwa merusak lingkungan berarti menempatkan materi dan makhluk lain di alam semesta ini sebagai objek yang tidak memiliki nilai pada dirinya sendiri, memiliki nilai sedikit saja dalam kaitannya dengan yang lain, dan tidak memiliki dimensi ilahi sama sekali (di mana realitas takbersyarat hadir di dalamnya).

Kesimpulan akhirnya kiranya adalah demikian. Materi memiliki nilai intrinsik pada dirinya sendiri. Ia memiliki peran di dalam tata alam semesta. Materilah yang membangun keseimbangan alam bagi kelangsungan hidup manusia. Lebih lagi, materi memiliki dimensi ilahi dan mengambil bagian dalam eksistensi ilahi. Merusak alam sama dengan merusak materi dan merusak hidup manusia sendiri.

Kedua, pemikiran mereka menyentuh kehidupan. Apakah kehidupan itu muncul secara otomatis? Teilhard mungkin tidak akan menjawab bahwa kemunculannya bersifat otomatis. Bahasa yang digunakannya adalah terarah. Kehidupan lahir karena sudah ada keterarahan sejak alam semesta ini dijadikan. Ketika granulasi yang menjadikan bahan dasar materi ini terjadi, 
sudah ada keterarahan bahwa evolusinya akan mengarah pada proses kompleksitas, yang kelak melahirkan materi-materi berat dan akhirnya kehidupan. Jadi, keterarahan kepada lahirnya, kehidupan dan kesadaran sudah ada dalam inti materi. Spitzer sendiri tidak bicara bagaimana kehidupan lahir di Bumi atau di alam semesta ini. Meski demikian, ia selalu merujuk pada pembedaan antara alam semesta yang antropis dan yang non-antropis, yaitu alam semesta yang melahirkan kehidupan dan yang tidak melahirkan kehidupan. Ketepatan nilai pada setiap konstanta, kombinasi konstanta-konstanta itu, serta relasi konstanta-konstanta itu dengan materi adalah kunci bagi lahirnya kehidupan.

Mengacu pada pendapat Teilhard dan Spitzer, kita dapat menyimpulkan bahwa materi yang menyusun makhluk hidup adalah sama dengan yang menyusun alam semesta. Lompatan dari materi berkesadaran terbatas menjadi makhluk berkesadaran, dari mati menjadi hidup, menjamin argumen ini. Karena itulah, semua makhluk hidup adalah integral dengan kosmos; artinya mereka semua berasal dari bahan dasar yang sama, yang jumlahnya berlimpah di alam semesta, serta mereka tidak dapat hidup di luar alam semesta, bahkan tak dapat hidup di luar lingkungan yang melahirkannya.

Dalam pemikiran Teilhard dan Spitzer tersirat bahwa kehidupan adalah berharga. Teilhard mengatakan bahwa kelahirannya hanya satu kali saja; Spitzer mengatakan kelahirannya bergantung pada berbagai macam faktor. Implikasinya adalah bahwa kehidupan ini perlu dijaga dan dipelihara agar tetap lestari. Dalam batasan tertentu, alam memiliki mekanisme untuk memperbaiki dirinya sendiri. Ketika hutan hangus terbakar karena diterjang awan panas dari letusan gunung berapi, berbagai benih tanaman tidak mati. Mereka akan menumbuhkan tunas baru di atas tanah yang hangus dan sudah diselimuti abu vulkanik. Sisa-sisa kebakaran itu memberi unsur hara baru bagi tanah dan menyuburkan generasi tanaman baru, yang kelak menghutankan kembali kawasan itu.

Kelahiran Bumi yang bergantung pada berbagai macam faktor ini menunjukkan bahwa Bumi kita sebenarnya juga terbatas. Terbatas di sini bukan saja dalam hal umur, tetapi juga sumber-sumber alam yang terdapat di dalamnya. Meskipun jumlahnya berlimpah, namun ada masa di mana sumber-sumber alam itu akan habis jika si pengguna tidak bijak dalam menggunakannya. Jika laju eksploitasi lebih cepat daripada laju pembaruan yang dilakukan oleh Bumi, tentu saja suatu ketika manusia tidak akan menemukan lagi sumber-sumber itu karena habis terkonsumsi.

Mengingat bahwa lahirnya kehidupan hanya satu kali saja, menurut Teilhard, serta bergantung pada banyak aspek, menurut Spitzer, kehidupan ini adalah berharga. Usaha untuk menjaga kelestarian dan kelangsungan hidup di alam semesta adalah sesuatu yang imperatif. Kesadaran bahwa Bumi terbatas dan kandungan sumber alamnya terbatas tentu akan mengubah cara manusia memperlakukan Bumi dan menggunakan sumber alam tersebut. Maka dari itu, diperlukan cara-cara baru untuk menggunakan sumber-sumber yang dikandung oleh Bumi secara arif.

Ketiga, Teilhard dan Spitzer pun menyinggung tentang keberadaan yang ilahi. Menurut Teilhard, fase akhir dari evolusi itu adalah suatu kesadaran yang paling agung di antara kesadaran-kesadaran yang lain. Titik Omega didefinisikan sebagai kesadaran agung ini. Dengan argumen bahwa titik Omega ini menyatukan segala sesuatu namun tidak meleburkannya dan tidak menghilangkan ciriciri otentik setiap personanya, dan model ini ternyata sama dengan pemikiran Kristen tentang Kristus yang menyatukan segala sesuatu pada diriNya, titik Omega ini kemudian didefinisikan sebagai Kristus kosmis. Dari idea tentang titik Omega yang identik dengan Kristus kosmis ini, kemudian ditarik argumen ke awal pembicaraan lagi. Jika akhirnya segala sesuatu disatukan dengan yang ilahi, dan yang ilahi ini adalah kesadaran agung, maka kesadaran-kesadaran lain yang ditarik kepadanya adalah juga berciri ilahi.

Menurut Spitzer, data-data mutakhir dari bidang fisika serta sejumlah teori yang sudah banyak diakui oleh para fisikawan kontemporer membangun kerangka pikir yang masuk akal tentang Tuhan. Hampir tidak mungkin menolak bahwa ada Tuhan yang menciptakan alam semesta. Dalam hal materi, Spitzer sampai pada pokok pikiran bahwa segala sesuatu didasari oleh realitas tak-bersyarat, yaitu yang ilahi sendiri. Karena itulah, sama dengan Teilhard, Spitzer membuka ruang baru, bahwa materi pun memiliki dimensi keilahian. Materi tidak sekadar materi; tumbuhan tidak sekadar tumbuhan; hewan tidak sekadar hewan; manusia tidak sekadar manusia, 
di mana yang material dan ilahi terpisah. Di dalam yang material terdapat yang ilahi.

Ide mengenai materi yang memiliki dimensi keilahian ini membuka kemungkinan baru bagi orang-orang yang percaya Tuhan, bagaimana mereka menghidupi iman pada masa kini. Beriman berarti juga menjaga dan merawat alam dan segala makhluk yang hidup di dalamnya. Adalah benar bahwa kita bertemu wajah Tuhan dalam diri sesama. Tetapi kini, adalah benar juga bahwa kita bertemu Tuhan di dalam alam semesta.

\subsection{Ecoteologi Teilhard}

Apa yang secara baru ditawarkan oleh Teilhard dalam hal evolusi adalah pertama, arah evolusi alam semesta yang menuju pada suatu kompleksitas. Kompleksitas tidak hanya sampai pada taraf kesadaran tapi terus maju hingga sampai taraf berefleksi, memiliki kebebasan, dan membentuk lapisan noosfer yang memiliki kemampuan memengaruhi lingkungan Bumi, dan bahkan cuaca di Bumi. Kemampuan berpikir ini adalah potensi manusia untuk mengetahui alam semesta dan untuk menguasainya, sebagaimana disinggung oleh filsuf Inggris Francis Bacon.

Implikasinya adalah manusia harus membangun dunia sebagai kontribusinya yang paling penting. Membangun dunia berarti manusia bergerak dari individual ke personal dan akhirnya ke kolektif. ${ }^{12}$ Cara pandang individual yang cenderung memecah, mengelompokkan berdasarkan ras, kepentingan, dan nilai ekstrinsik harus diubah menjadi cara pandang personal yang menghargai setiap realitas karena martabat dan nilai intrinsiknya. Eksploitasi alam demi keuntungan industri berarti kegagalan dalam menghargai martabat personal (personal dignity) dan kekudusan alam.

Dari yang personal ini diharapkan tumbuh pembangunan dunia yang kolektif, yaitu mengenali dan menyadari bahwa pusat-pusat lain di luar dirinya adalah pribadi-pribadi yang memiliki martabat dan nilai pada dirinya sendiri. Setiap manusia dipanggil untuk mencintai sesamanya dan alam semesta. Gerak menuju yang kolektif ini mengandung dimensi waktu ke masa depan juga. Apa yang kita lakukan terhadap alam semesta pada masa kini akan menentukan apa yang akan dialami oleh generasi manusia di masa mendatang.

Kedua, Teilhard membedakan noosfer dan biosfer. Noosfer adalah lapisan kesadaran yang mampu berefleksi dan berpikir. Biosfer adalah lapisan yang berkesadaran atau memiliki psyke. Ada dua hal yang bisa disimpulkan mengenai keterkaitan antara biosfer dan noosfer. Pertama, biosfer selama berjuta-juta tahun membangun jaringan kehidupan yang kompleks. Kesalingtergantungan antara satu makhluk dengan makhluk lain tumbuh, mulai dari sistem rantai makanan hingga reproduksi. Biosfer juga membangun dan mempertahankan parameterparameter yang memungkinkan evolusi materi yang berkesadaran ini berlanjut terus. Parameter yang dimaksud misalnya, salinitas air laut, komposisi gas di atmosfer, dan keasaman tanah. Karena tercipta kestabilan, biosfer mampu melahirkan lapisan baru yaitu noosfer. Kedua, kestabilan ini masih terus dibutuhkan untuk mempertahankan lapisan kesadaran itu sendiri dan lapisan kesadaran yang berefleksi yang telah dilahirkannya. Dengan begitu, ada hubungan erat antara biosfer dan noosfer. Hubungan itu kiranya bukan hubungan searah, tapi hubungan dua arah, timbal balik.

Implikasinya adalah bahwa merusak alam dan ekspolitasi alam dengan tidak memerhatikan keseimbangan biosfer tidak akan mempertahankan kelangsungan biosfer itu sendiri. Penggunaan teknologi penghasil energi yang menghasilkan limbah berbahaya bagi lingkungan tidak akan mampu mempertahankan biosfer untuk kelangsungan kehidupan.

\subsection{Ecoteologi Spitzer}

Apa yang ditawarkan Spitzer secara baru adalah mengenalkan Tuhan pada sidang pembaca melalui sains. Ia sangat kuat menunjukkan pada bab awal bahwa alam semesta yang kita huni hadir karena suatu rancangan, bukan suatu kebetulan semata. Lepas dari siapa perancangnya, rancangan ini membentuk suatu sistem yang hidup. Hidup bukan sekadar dalam arti hidup seperti makhluk hidup, tetapi hidup berarti ada interaksi antara materi di dalamnya, antara konstanta-konstanta dan hukum-hukum fisika.

Tentu saja manusia tidak berkuasa mengubah, misalnya nilai-nilai konstanta alam semesta. Akan tetapi, ia mampu dan berkuasa untuk mengubah rancang bangun alam semesta yang lebih sederhana, misalnya lingkungan tempat tinggalnya yaitu Bumi. Apa yang sudah disimpan dan disusun secara "rapi" oleh alam, misalnya uranium dan karbon, dapat dibongkar dan 
disusun ulang oleh manusia menurut kebutuhan dan kepentingannya sendiri. Tidak mengherankan bahwa perubahan ini membawa bencana bagi hidup manusia sendiri. Maka dari itu, dengan menyadari bahwa alam semesta, khususnya Bumi kita ini, adalah suatu sistem yang hidup, bergerak, dan dinamis, manusia dituntut untuk dapat hidup berdampingan dengannya karena ia tidak dapat hidup juga tanpanya.

\section{KITAB SUCI DAN TRADISI GEREJA}

Pertanyaan yang pantas diajukan adalah apakah Kitab Suci dan tradisi Gereja bicara mengenai keterkaitan antara ilmu pengetahuan, teknologi, dan kesadaran lingkungan hidup. Jawabannya adalah ya, tapi dengan cara yang sederhana. Ilmu pengetahuan dan teknologi dimengerti sebagai dimensi kreatif manusia untuk hidup dalam alam semesta dan mengolah alam semesta itu untuk mempertahankan kelangsungan hidupnya, bahkan untuk mencapai apa yang dicita-citakannya dalam konteks iman, yaitu bersatu dengan penciptanya sendiri.

Kitab Suci menekankan keteraturan seluruh tata ciptaan dan bukan manusia belaka; ada hubungan erat antara manusia, makhluk hidup bukan-manusia, dan alam lingkungan; sebagai makhluk spiritual, manusia bertanggungjawab atas kesejahteraan alam semesta dan makhluk lain di dalamnya.

\subsection{Materi dan Ketertataan Alam Ciptaan}

Secara tradisional cara pandang orang-orang kristen terhadap dunia dibentuk dan dipengaruhi oleh antroposentrisme. Manusia adalah pusat dan puncak segala ciptaan. Meski zaman Galileo Galilei sudah berlalu dan manusia tahu secara ilmiah bahwa dirinya tidak berada pada pusat alam semesta, manusia masih merasa dirinya sebagai puncak ciptaan; segala sesuatu yang ada di alam semesta, khususnya di muka Bumi, diciptakan semata-mata untuk kepentingan dirinya. Pandangan Gereja Konsili Vatikan II pun masih sempit; Gaudium et Spes no 12 menulis "Kaum beriman dan tak beriman hampir sependapat, bahwa segala sesuatu di dunia ini harus diarahkan kepada manusia sebagai pusat dan puncaknya."

Para pendukung antoposentrisme hampir selalu mengacu pada Kitab Kejadian bab 1 (Kej 1), khususnya ayat-ayat yang berbicara mengenai penciptaan manusia. Kisah naratif penciptaan sebenarnya tidak selesai pada Kej 1 tapi berlanjut hingga Kej 2:4a. Sayangnya, para pendukung antroposentrisme hanya mengambil kisah penciptaan manusia dari Kej 1:26 sampai Kej 1:28 yang seakan-akan melegitimasi eksploitasi alam semata-mata untuk kepentingan hidup manusia. Padahal Kitab Kejadian tidak dapat dilepaskan dari mitos-mitos kosmogenesis yang berkembang di daerah Timur Tengah kuno.

Kebanyakan mitos bangsa-bangsa Timur Tengah menggambarkan kebutuhan manusia untuk mempertahankan stabilitas bumi dan masyarakat. ${ }^{13}$ Di Mesopotamia, raja yang sesungguhnya adalah tuhan. Dialah pahlawan perang yang sukses mengatasi kekacauan alam semesta pada permulaan waktu. Perannya bukan pertama-tama sebagai pencipta. Penciptaan surga tempat para dewa dan bumi tempat manusia diciptakan oleh kekuatan ilahi baru terjadi setelah perang melawan kekacauan semesta usai. Tuhan sebagai pencipta rupa-rupanya tidak sepenting dirinya sebagai penguasa yang membangun tata alam semesta. Raja di tengah-tengah masyarakat, meskipun mendapatkan kuasa dari yang ilahi, tidaklah bersifat ilahi seperti raja-raja di Mesir. Mitos kosmogenesis Mesopotamia terdiri dari tiga unsur penting, yaitu perang kosmis, tindakan penciptaan, dan pembangunan tempat tinggal yang nyaman bagi dewa-dewa dan manusia.

Kisah penciptaan dalam tradisi Israel diawali dengan kalimat, "Pada mulanya Allah menciptakan langit dan bumi," dan diakhiri dengan kalimat, "Demikianlah riwayat langit dan bumi pada waktu diciptakan." Inti dari kisah ini adalah kisah penciptaan langit dan bumi, dan bukan penciptaan manusia atau makhluk hidup. Kisahnya diawali dengan suatu kekacauan yang digambarkan dalam ayat 2. Secara bertahap, Allah mengalahkan kuasa kekacauan itu. Ia memisahkan terang dari gelap; ia memisahkan air yang ada di atas dan yang ada di bawah dengan batas cakrawala. Ia memisahkan daratan kering dari lautan, tempat semua air di kolong langit dikumpulkan. Setelah proses penaklukkan ini berhasil, Allah memulai tindakan penciptaan. Ia menciptakan matahari, bulan, bintang, tumbuhan, hewan, dan akhirnya manusia. Penciptaan manusia hanyalah bagian dari penciptaan alam semesta dan proses penataan alam semesta menjadi teratur.

Dibaca dalam konteks tradisi Mesopotamia, manusia yang diciptakan serupa dan segambar 
dengan Allah tidak lain adalah penguasa alam semesta dengan tanggung jawab "menaklukkan" serta "menguasai." Mitos-mitos Mesopotamia tidak memiliki cerita semacam ini. Sang dewa pahlawan perang justru menciptakan dewadewa lain seturut citra dan rupanya sendiri untuk menguasai bagian-bagian dari alam semesta setelah dewa pahlawan itu mengalahkan kekacauan. Manusia tidak diciptakan serupa dan segambar dengan dewa-dewa. Kisah penciptaan manusia versi Israel adalah adaptasi dari mitos-mitos di Mesopotamia. Ini adalah kisah penciptaan makhluk yang memiliki derajat lebih tinggi daripada hewan dan tumbuhan, tetapi sedikit lebih rendah daripada dewa.

Tersirat di situ, tujuan manusia diciptakan adalah mengambil peran sebagai raja, yaitu menguasai alam semesta supaya keseimbangan dan ketertataan alam semesta yang sudah dimulai oleh Allah itu tetap terjaga. Kata "menaklukkan" dan "menguasai" bukan dimaksudkan untuk mengeksploitasi dan mengeruk alam dengan semena-mena demi kepentingan hidup manusia, tapi untuk merawat dan menjaga keseimbangan alam ini.

Semakin banyak ahli pada masa kini setuju bahwa kisah Nuh dan air bah dalam Kej 7-9 adalah narasi penciptaan yang kedua. Banyak tradisi terutama di Timur Tengah mengidentikkan kisah banjir bandang dengan kisah penciptaan. Banjir yang dimaksudkan bukanlah banjir sebagai peristiwa historis yang sungguh terjadi di masa lalu, melainkan suatu banjir purba yang membawa kekacauan, kehancuran, dan kegelapan. Surutnya banjir adalah awal ketertataan dan keteraturan alam semesta serta proses penciptaan.

Setelah banjir itu surut, Allah membuat perjanjian. Banyak orang menyangka bahwa perjanjian itu dibuat antara Allah dengan manusia, yaitu Nuh saja. Jika teksnya dibaca secara teliti, akan didapati bahwa perjanjian itu diadakan antara Allah "dengan kamu (manusia) dan keturunannya dan dengan segala makhluk hidup yang bersama-sama dengan kamu (manusia)" (Kej 9:9-10). Isi perjanjiannya adalah Allah tidak akan mendatangkan air bah lagi dan tidak akan membiarkan kekuatan samudera purba mengacaukan alam semesta yang sudah ditataNya. Lambang dari perjanjian itu adalah busur pelangi. Ini adalah lambang busur panah, tanda kemenangan pahlawan perang, yaitu Allah sendiri atas kekuatan kekacauan dan kehancuran purba. Dengan menggantungkan busur panah di langit, Allah menetapkan bahwa peperangan melawan kekacauan sudah berakhir. Dan manusia diberi kuasa oleh Allah sendiri untuk "menaklukkan" dan "menguasai" alam ciptaan ini dengan maksud agar keseimbangan serta ketertataan alam semesta yang sudah dibuat oleh Allah tetap terjaga.

\subsection{Kehidupan dan Penderitaan}

Peran manusia sebagai gembala alam ciptaan tergambar dalam sistem Sabat dan Yobel dalam tradisi Yahudi kuno. Sistem ini diadakan untuk membarui dan mendapatkan kembali seluruh ciptaan agar tidak lenyap musnah. Kel 31:10-13 menggambarkan bahwa Sabat adalah "perjanjian abadi" antara manusia dengan YHWH yang berlaku secara perorangan dan berdasarkan pada tradisi Priest secara legitim di dalam kisah penciptaan (Kej 2:3). Setidaknya ada tiga perhentian yang dijalani oleh orang-orang Yahudi, yaitu hari Sabat yang dilaksanakan seminggu sekali, tahun Sabat yang hadir setiap tujuh sekali, dan tahun Yobel yang jatuh pada tahun yang kelimapuluh. Mengenai hal ini tercantum di dalam Kitab Imamat bab 25 (Im 25). Utamanya, Sabat mengingatkan manusia mengenai suatu kebenaran bahwa alam semesta ini adalah ciptaan milik Allah. Tugas kita manusia adalah menjaga dan merawat seluruh alam ciptaan ini. Dalam arti tertentu, hari Sabat dapat dikatakan sebagai hari kesadaran lingkungan hidup. ${ }^{14}$

Secara terinci, Im 25 mengatakan bahwa setiap tahun ketujuh, orang tidak boleh mempekerjakan ternak di ladang dan harus menghentikan kegiatan bertani. Hewan ternak mendapat perhentian pada tahun itu. Tanah tidak boleh ditaburi benih dan harus dibiarkan ditumbuhi ilalang dan semak-semak liar. Sementara itu pada tahun Yobel, orang tidak hanya dilarang mempekerjakan hewan dan mengolah tanah ladangnya, tetapi mereka harus kembali ke tanah pusaka mereka masing-masing. Mereka juga harus mengembalikan tanah yang sudah mereka beli kepada pemiliknya yang semula. Tanah dalam tradisi Israel kuno tidak dapat dijual secara mutlak karena tanah adalah milik YHWH (bdk. Mzm 24:1). Pada tahun inilah orang yang mampu harus menebus tanah yang sudah "terjual" itu dan mengembalikan pada pemiliknya yang semula.

Dengan sistem Sabat dan Yobel itu, manusia selalu diingatkan lagi dan lagi bahwa seluruh 
sumber daya alam harus digunakan dengan pertanggungjawaban kepada Tuhan. Apa yang hendak dilawan dan dihindari oleh Im 25 adalah sikap rakus dan serakah manusia yang mengeksploitasi mereka yang miskin dan lemah. Yang dimaksud sebagai yang lemah di sini bukan saja sesama manusia, tapi juga mereka yang tidak dapat dan tidak mampu membela dirinya sendiri di hadapan manusia yang memiliki kekuatan setaraf lebih rendah dari Allah sendiri. Mereka ini adalah hewan, tumbuhan, dan tanah. Sistem Sabat dan Yobel juga didirikan untuk mengembalikan keseimbangan ecologis dan harmoni alam semesta. ${ }^{15}$

\subsection{Diciptakan dalam Kristus}

Apakah ajaran-ajaran Yesus yang menjiwai seluruh tulisan Perjanjian Baru juga bicara mengenai harga kehidupan? Jawabannya adalah ya. Manifesto Yesus di Nazaret yang diceritakan dalam Luk 4:18, 19 adalah pernyataan misi Yesus di hadapan publik. Tugas yang diemban-Nya adalah menegakkan keadilan sosial dan ecologis, serta pembebasan secara penuh. ${ }^{16}$ Misi Yesus ini tidak hanya ditujukan bagi manusia saja. Di akhir kutipan-Nya atas Kitab Yesaya, Ia menyertakan juga tugasNya untuk memberitakan bahwa tahun rahmat Tuhan telah datang. Tahun rahmat Tuhan adalah tahun Yobel. Tidak mengherankan pula bahwa Ia kerap menggunakan keindahan alam ciptaan untuk menyampaikan ajaran-ajarannya.

Dari seluruh tulisan Injil, Injil Yohanes 1:118 adalah yang paling lugas membahasakan hubungan Yesus Kristus dengan kosmos. Yohanes menginterpretasi ulang kisah penciptaan dari Kitab Kejadian di dalam prolognya. Sabda yang dahulu keluar dari mulut Allah dan menciptakan alam semesta adalah Yesus Kristus sendiri yang menjadi manusia. Pada ayat 3 dikatakan, "Segala sesuatu (ta panta) diciptakan (egeneto) oleh Dia, dan tanpa Dia tak sesuatu pun yang tercipta diciptakan." Yang khas di sini adalah bahwa logos mendapat penekanan, yaitu bahwa dia punya peran sebagai perantara antara Allah pencipta dan ciptaan. Lebih khusus lagi, logos ini adalah Kristus Yesus yang lahir sebagai manusia di Nazareth.

Karena kesadaran akan hidup dan karya Yesus bersifat universal dan kosmis, Yohanes juga menginterpretasikan kedosaan dan keselamatan secara kosmis. Keselamatan adalah pemenuhan penciptaan di dalam diri Yesus Kristus. Maka apa yang baru dan berbeda dengan Kitab Kejadian adalah bahwa pencipta adalah juga sekaligus penebus/penyelamat. Ini menjadi jelas dalam Rom 8: 18-25 tentang pembebasan makhluk hidup. Prolog Injil Yohanes ini memperlihatkan dengan jelas bahwa kemanusiaan dan alam semesta memiliki kesamaan dalam sejarahdan kesamaan dalam tujuan.

\section{PENUTUP}

Akhirnya kita melihat bahwa kemajuan sains memiliki dua wajah sekaligus. Di satu sisi, sains dapat memajukan teknologi bahkan sampai dapat merusak lingkungan karena kemampuannya mengubah susunan alam semesta. Di sisi lain, kemajuan itu dapat membuat manusia terdiam, termenung, serta merefleksikan kehadirannya di alam semesta, keterhubungannya dengan alam semesta, serta kehadiran pencipta sendiri. Kesadaran inilah yang membuatnya menghargai alam semesta tempat ia hidup dengan cara menjaga dan merawatnya. Dengan demikian tergantung pada manusianya sendiri apakah ia memanfaatkan ilmu pengetahuan dengan moralitas yang benar atau tidak. Tanpa moralitas, manusia menggunakan ilmunya untuk bertindak semena-mena.

Teilhard dan Spitzer memberi perspektif lain dalam memandang kemajuan sains, dan perspektif ini sejalan dengan Kitab Suci dan tradisi Gereja. Sains mengantar manusia pada sikap ecosentris, yaitu menyadari bahwa:

Secara materi dirinya berasal dari alam semesata. Tubuhnya disusun oleh materi-materi yang sama yang menyusun alam semesta dan makhluk hidup lain di dalamnya. Kebertubuhannya membuat manusia terus bergantung pada alam semesta demi kelestarian hidupnya. Manusia dilahirkan dan diberi makan oleh alam semesta.

Setiap materi di alam semesta, apapun bentuknya dan bagaimanapun susunannya memiliki nilai interinsik, yaitu nilai pada dirinya sendiri yang terberi karena dia ada. Karena itulah, setiap dari mereka patut dihargai dan dihormati karena keberadaannya. Pandangan kita menjadi ecosentris.

Setiap materi di alam semesta terhubung satu sama lain. Jadi yang terhubung bukan hanya manusia. Hubungan ini menjadi satu jaringan alam semesta yang hidup. Materi yang satu dan makhluk yang satu tidak dapat hidup tanpa materi yang lain dan makhluk yang lain. 
Setiap materi memiliki ciri ilahi di dalamnya. Ciri ilahi inilah yang mendasari keberadaannya. Orang beriman tentu akan memiliki horizon baru dalam cara berimannya. Menjaga kelestarian alam menjadi model beriman pada masa kini.

Berdasarkan kesadaran inilah diharapkan tumbuh kesadaran ecologis, yaitu kesadaran akan keberhargaan lingkungan tempat tinggal, makhluk lain - selain manusia -, serta segala unsur mineral di dalamnya.

\section{Christoforus Bayu Risanto}

Studi Program Master di Department of Atmospheric Science and Meteorology, Creighton University, Nebraska, USA: bayu0106@gmail. com

\section{CATATAN AKHIR}

1 Isotop adalah partikel atom yang tidak stabil karena ada kelebihan massa atom.

2 Reaksi fisi adalah reaksi nuklir yang terjadi karena pembelahan inti atom. Pembelahan ini menghasilkan energy serta partikel atom yang lebih ringan.

3 Paparan radiasi di Fukushima adalah 400.000 mikrosievert. Risiko terkena kanker melonjak ketika paparan berada pada kisaran 100.000 mikrosievert.

4 Ahmad Arif, "Jepang di Simpang Jalan Nuklir", 9.

5 P. Teilhard de Chardin, The Phenomenon of Man, diterjemahkan dari Le Phenoménè Humain, oleh Bernard Wall, 55

6 P. Teilhard de Chardin, The Phenomenon of Man, 79.

7 P. Teilhard de Chardin, The Phenomenon of Man, 102.

8 P. Teilhard de Chardin, Le Phenoménè Humain, Édition de Seuil, 181.

9 P. Teilhard de Chardin, The Phenomenon of Man, 263.

10 ... "creation", in a broader way as "the ultimate fulfilment of conditions by the unconditioned Reality itself." (R. Spitzer, New Proofs for the Existence of God, 142)

11 Faricy, "The Explanation of Nature and Teilhard's Ecotheology of Love", dalam C. DeaneDrummond, Pierre Teilhard de Chardin on People and Planet, 127.

12 B. R. Hill, "Teilhard's Vision and the Environment”, 55.

13 D. Bergant, "Is the Biblical Worldview Anthropocentric?" New Theology Review vol. 4 no. 2,7 .
14 J. Chakkuvarackal, "Biblical Perspective on Creation, Ecology, and Human Responsibility", Mission Today, vol. VI no. 4, 345.

15 J. Chakkuvarackal, "Biblical Perspective", 346.

16 J. Chakkuvarackal, "Biblical Perspective", 350.

\section{DAFTAR PUSTAKA}

Al Gore, 2010. Our Choice; Rencana untuk Memecahkan Krisis Iklim (terj. HardonoHadi PhD), Kanisius, Yogyakarta.

Arif, Ahmad, 2011. "Jepang di Simpang Jalan Nuklir", Kompas 20 Maret

Bergant, Dianne, 1991. "Is the Biblical Worldview Anthropocentric?", New Theology Review Vol. 4 No. 2, The Liturgical Press,Collegeville, 5-14.

Chakkuvarackal, Johnson, 2004. "Biblical Perspective on Creation, Ecology, and Human Responsibility", Mission Today Vol. VI No. 4, Sacred Hearth Theological College, Meghalaya, 338358.

De Chardin, Teilhard, 1955. Le Phénomène Humain, Édition du Seuil, Paris.

De Chardin, Teilhard, 1963. The Phenomenon of Man (terj. Bernard Wall), Collins Sons $\&$ Co Ltd, London.

Deane-Drummond, Celia, 2006. Pierre Teilhard de Chardin on People and Planet, Equinox Publishing Ltd, London.

Forbes, R.J., 1971. The Conquest of Nature: Technology and its Consequences, Penguin Books, Middlesex.

Hill, Brennan R., 2001. "Teilhard's Vision and the Environment", Horizon Vol 28 No 1, Villanova University, Villanova 2001, 50-67.

Jesuit Conference of Asia Pacific, 2011. Reconcilliation with Creation, Jesuit Conference of Asia Pacific, Manila.

Konsili Vatikan II, 2002. Dokumen Konsili Vatikan II (terj. R. Hardawiryana, SJ), Dokumentasi dan Penerangan KWI OBOR, Jakarta

Spitzer, Robert J., 2010. New Proofs for the Existence of God, Eerdmans Publishing, Michigan. 